\title{
Intra-Household Roles in Cocoa Production in Ondo State, Nigeria
}

https://dx.doi.org/10.4314/jae.v22i3.8

\section{Akinnagbe Oluwole Matthew}

Department of Agricultural Extension and Communication Technology

Federal University of Technology, Akure, Nigeria.

E-mail: omakinnagbe@futa.edu.ng

Tel: +2348035399151

\section{Adeniran Tosin Precious}

Department of Agricultural Extension and Communication Technology

Federal University of Technology, Akure, Nigeria.

E-mail: adenirantosin456@yahoo.com

Tel: +2348037536366

\section{Adeniran Adebayo Adeniyi}

Department of Agricultural Extension and Management, Federal College of Agriculture, Ibadan

E-mails: adeniranbayo@yahoo.com

Tel: +2348185585390

\section{Abstract}

This study examined intra-household roles in cocoa production in Ondo State, Nigeria. Multistage sampling procedure was used to select sample of 70 cocoa farmers. Primary data were collected with the aid of structured interview from the cocoa farmers. Data were analysed using frequency, percentage and mean statistic. Results reveals that family labour (81.4\%) was the main sources of labour used in cocoa production and majority (51.4\%) used their personal saving as the major sources of fund for cocoa production. Fellow farmers (90.0\%) and radio (62.9\%) were the main sources of information on cocoa production. Men were involved in planting cocoa seed at the nursery (90.0\%). Women were more involved in assembling of harvested pods (68.6\%). Men and women were more involved in transplanting of seedlings permanent site $(84.3 \%, 81.4 \%)$ and removal of beans from the pod $(72.2 \%, 80.0 \%)$. Intra-household roles in cocoa production revealed that men and male children were more involved in preparation of shade at the nursery (92.9\%), land clearing (100.0\% and $81.4 \%)$, weeding (97.1\% and $81.4 \%)$, spraying of herbicides $(97.1 \%$ and $75.7 \%)$, spraying of pesticides $(100.0 \%$ and $78.6 \%)$, removal of mistletoe (98.6\% and 81.4\%) and harvesting (100.0\% and 84.3\%), respectively. Women and female children were more involved in sundrying of cocoa beans (82.9\% and 90.0\%). All (men, women, male and female children) were more involved in nursery maintenance $(92.9 \%$, $80.0 \%, 78.8 \%$ and $74.3 \%$ ). The major constraints to cocoa production were unavailability of labour to carry out essential farm activities $(\overline{\mathrm{X}}=3.56)$, unfavourable prevailing weather condition $(\overline{\mathrm{X}}=3.54)$ and poor extension agent-farmers contact $(\overline{\mathrm{X}}=3.51)$. The study recommends that issues relating to cocoa production should be addressed to specific 
Creative commons User License: CC BY-NC-ND

Abstracted by: EBSCOhost, Electronic Journals Service (EJS), Google Scholar, Journal Seek, Scientific Commons,

Food and Agricultural Organization (FAO), CABI and Scopus
Journal of Agricultural Extension

Vol. 22 (3) October, 2018

ISSN(e): 24086851; ISSN(Print); 1119944X

http://journal.aesonnigeria.org

http://www.ajol.info/index.php/iae

Email: editorinchief@aesonnigeria.org

individual household members performing such roles in order to enhance productivity.

Keywords: Intra-household, roles, cocoa production

\section{Introduction}

The significant role of cocoa as a driver of economic growth has gained overall acceptance in all cocoa growing economies. In Nigeria, cocoa has been the main agricultural stake of the economy. Cocoa has been a major source of income for many Nigerians and a major source of foreign exchange earnings for the country. It is an important generator of income for most rural farmers in Nigeria especially in the South West and serves as a backbone for their livelihood (Adeniyi, and Ogunsola, 2014).

Cocoa is an important source of raw materials, as well as source of revenue to governments of cocoa producing states (Olowolaju, 2014). Apart from its contribution to the nation's economy, cocoa is a plant-based food that contains carbohydrates, fats, proteins, natural minerals and some vitamins and like several other plant foods such as tea, red wine, fruits, vegetables and nuts cocoa contains a group of compounds which exhibit health benefits (Taubert et al, 2007). Nigeria is the fourth largest producer of cocoa after Cote D'ivoire, Ghana and Indonesia contributing 12\% of total world production (ICCO, 2014).

Fourteen States grow cocoa in Nigeria. They are Abia, Adamawa, Akwa Ibom, Cross River, Delta, Edo, Ekiti, Kogi, Kwara, Ogun, Ondo, Osun, Oyo and Taraba. The South West is regarded as the cocoa belt of the country, it accounts for $70 \%$ of Nigeria's annual cocoa production (Michael and Nzeka, 2011). Nigeria has the potential to produce over 300,000 tons of cocoa beans per year (Nigeria Agriculture Statistics, 2014). The rural households are key players in the business of agriculture in the country especially within rural communities. It is therefore believed that for agriculture to developed, rural households should be given greater priority in the production chain. The study therefore focuses on roles of households in cocoa production.

\section{Objectives of the study}

The overall objective of the study was to examine intra-household roles in cocoa production in Ondo State, Nigeria.

Specifically, the study sought to:

i. identify the sources of information used by cocoa farmers;

ii. determine the intra-household roles in cocoa production; and

iii. examine the constraints facing the respondents in cocoa production.

\section{Methodology}

The study was carried out in Ondo State. The State has 17 Local Government Areas (LGAs). Cocoa farmers constituted the population for the study. Agriculture is the main occupation of the people. The main cash crops are cocoa, cashew and kolanut. A multistage sampling procedure was used in selecting the respondents for the study. 
The first stage involved purposive selection of Owena/ldanre cocoa production zone because of the concentration of cocoa farmers in the zone. The second stage involved purposive selection of five communities because of the highest cocoa farming activities in the area. At the third stage, fourteen heads of households' farmers were selected each from the five villages making a total of seventy respondents. Data were collected from respondents with the use of interview schedule. The interview schedule contained relevant questions on each of the objectives. Content and face validity was done to ensure that the instrument collected the data it intended to collect. Experts in the field of Agricultural Extension and in cocoa production were given the instrument to review independently. The possible suggestions and comments made were used in restructuring the instrument before field administration.

To ascertain the intra-household roles in cocoa production, activities on cocoa production were listed for the respondents to indicate who among the households' members (men, women, male children and female children) performed each of the task/activities. These activities include: land preparation, planting, weeding, manuring, harvesting among others. To ascertain the constraints militating against cocoa production, a list of possible constraints were made available. Respondents were asked to indicate the level of the seriousness of each constraint on a 4- point Likert- type scale of great extent $=4$, to some extent $=3$; to a very little extent $=2$ and to no extent $=1$. Any variable with a mean of 2.5 and above was regarded as major constraint to cocoa production. Data were analysed using frequency count, percentage and mean statistic.

\section{Results and Discussion}

\section{Membership of Social Organisation}

Figure 1 reveals that the majority (99.0\%) of the cocoa farmers belong to social organisation. The results further reveals that, out of the $99.0 \%$ of the cocoa farmers that belong to social organisation, about $42 \%$ belong to cooperative society, while the rest belonged to other organisations such as political group, religious group among others. Involvement of farmers in social organization like cooperative society and cocoa farmers group could enhance diffusion of information on cocoa among the farmers. It will also enhance farmers' access to government assistance in form of loans and other inputs. 
Creative commons User License: CC BY-NC-ND

Abstracted by: EBSCOhost, Electronic Journals Service (EJS),

Google Scholar, Journal Seek, Scientific Commons,

Food and Agricultural Organization (FAO), CABI and Scopus
Journal of Agricultural Extension

Vol. 22 (3) October, 2018

ISSN(e): 24086851; ISSN(Print); 1119944X

http://journal.aesonnigeria.org

http://www.ajol.info/index.php/iae

Email: editorinchief@aesonnigeria.org

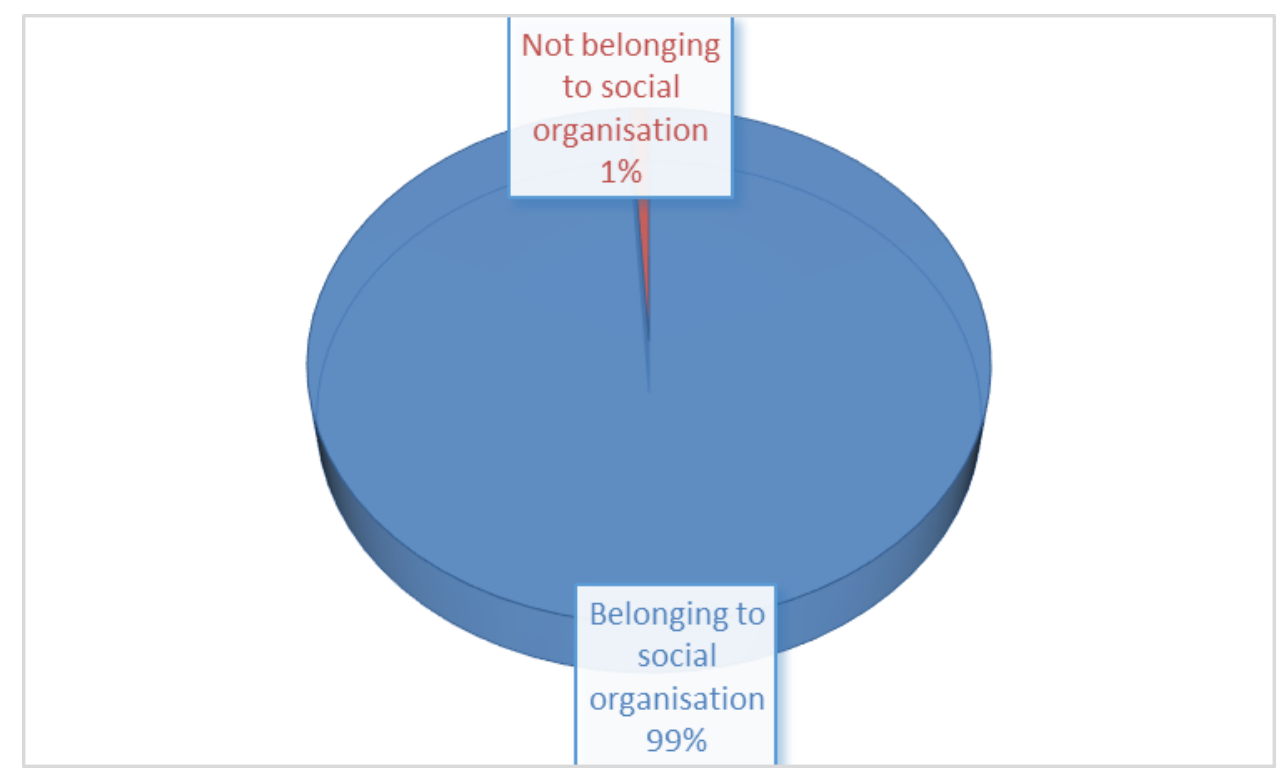

Figure 1: Membership in social organisation

\section{Source of Farm Labour}

Figure 2 reveals that the majority $(81.4 \%)$ of the cocoa farmers used family labour while $18.6 \%$ of the farmers used hired labour in their cocoa plantation. This implies that cocoa production activities were basically done by the family labour who could be paid in kind for their job done. The implication of this is that more hands are involved in the cocoa production activities which invariably could boost production and output. Farmers not using hired labour in cocoa farms could result in reduction of cost of production. This additional cost could affect farmers' profit.

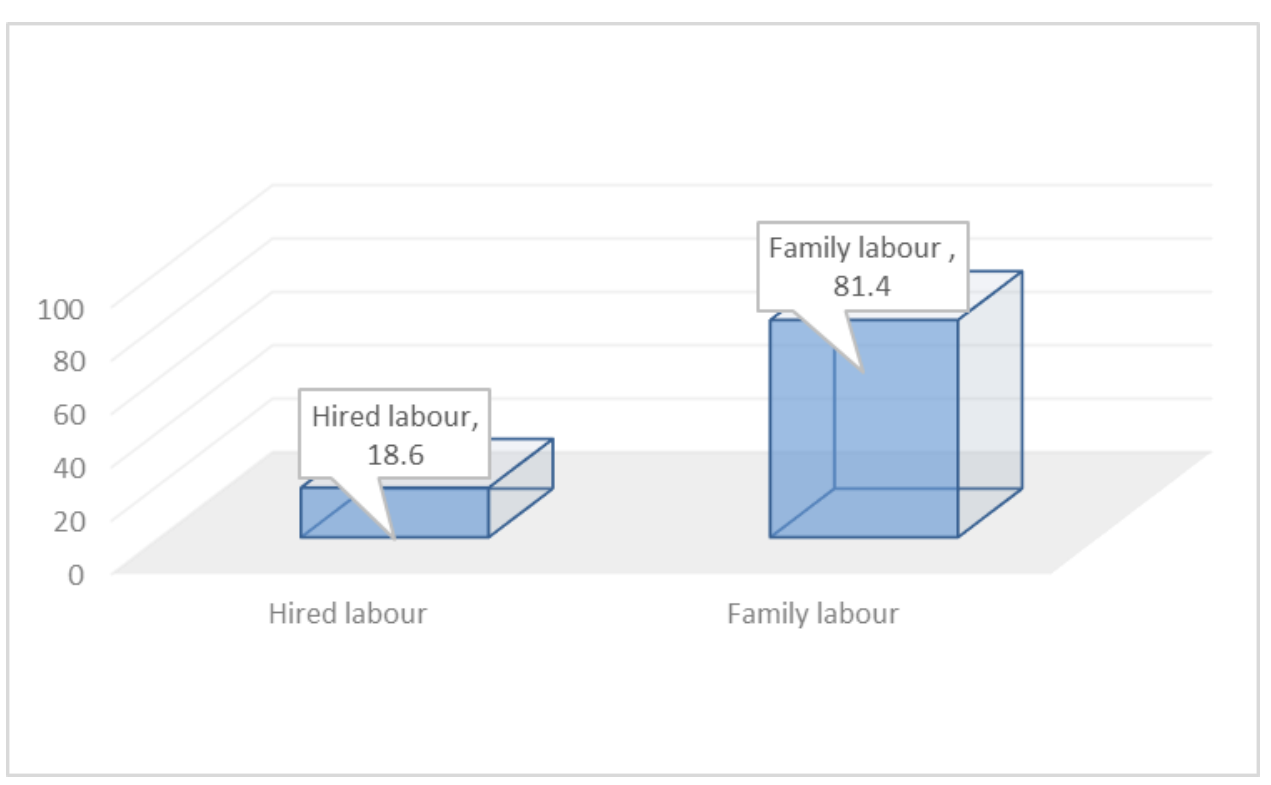

Figure 2: Sources of farm labour 


\section{Management System Adopted in Cocoa Farm}

Figure 3 reveals that the majority $(88.6 \%)$ of the cocoa farmers adopted selfmanagement system while the remaining $11.4 \%$ adopted lease management system. This implies that the cocoa farmers manage their cocoa farms by themselves, hence they will be able to be expose to more management activities in the farm. Also, the decision on any of the activities will be their sole responsibility. The advantages this could have is that; it will reduce their farming expenses like rentage cost. This study is in agreement with that of Akinnagbe (2017) that the majority of both the participant farmers $(75.0 \%)$ and control group (76.7\%) adopted self-management system in their farm.

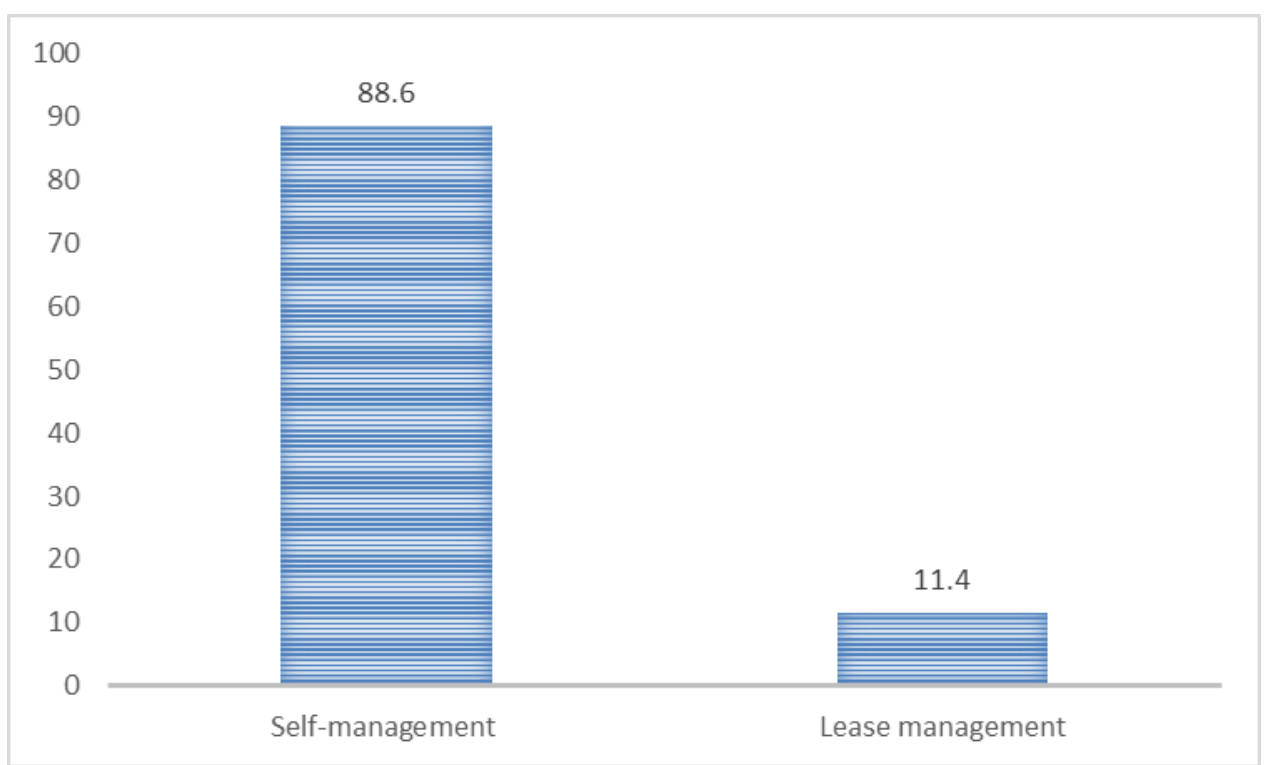

Figure 3: Management system adopted in cocoa farm

\section{Source of Fund for Cocoa Management}

The result in Figure 4 shows that the majority of the farmers sourced their fund for cocoa farming through personal savings $(51.4 \%)$. About $44 \%$ also source their money through cooperative society. Financing cocoa farms through personal savings may limit the farmers' farm-size under cultivation. This is evident in the size of cocoa farms cultivated by the farmers. Also, financing cocoa farms through personal saving could also hinder adoption of improved cocoa technologies. Any technologies beyond the financial capability of the farmers could lead to rejection. This could be possible because the farmers may not be able to finance such technology. 


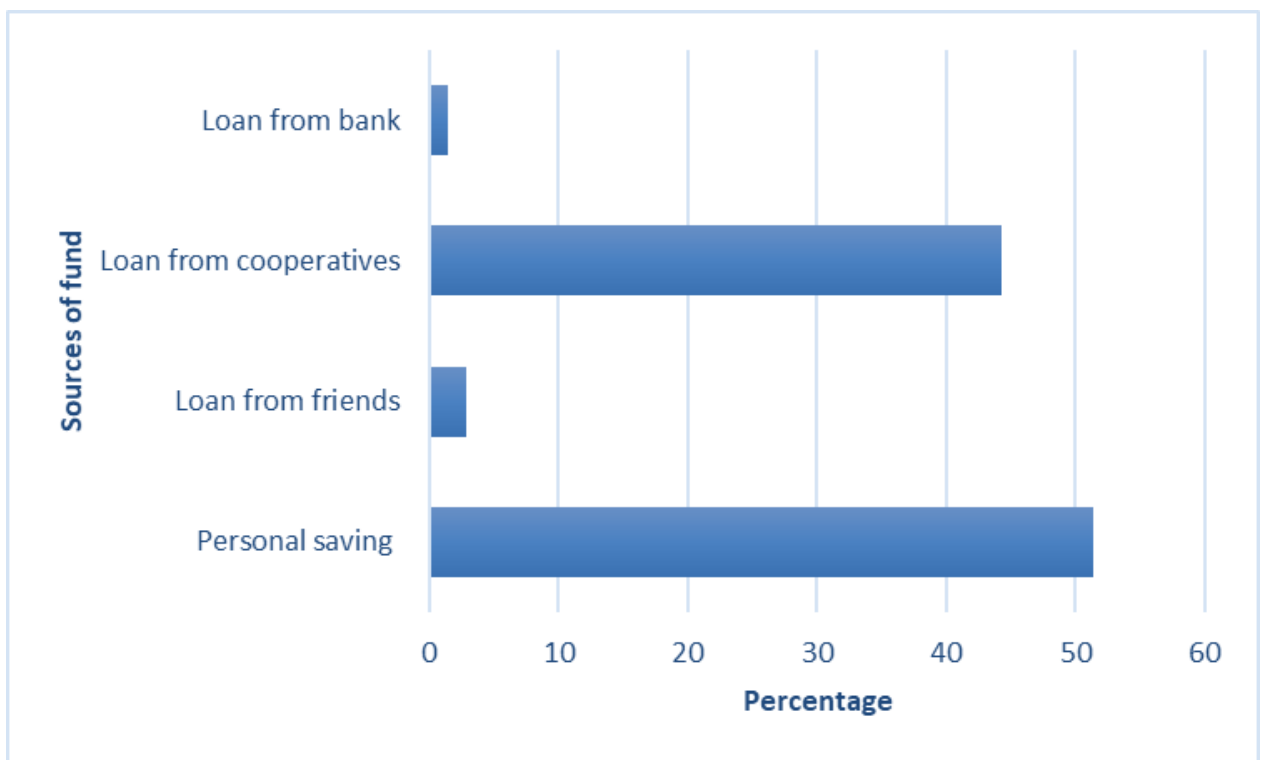

Figure 4: Sources of fund

\section{Source of Information on Cocoa Production}

Table 1 shows that the majority $(90.0 \%)$ of the respondents assess information on cocoa production through fellow farmers while $62.9 \%$ got the information through radio. All human societies depend very much on information for existence. It is an essential resource for individual growth and survival. An informed mind is an enriched mind and if one is not informed he will be deformed. Depending on fellow farmers as sources of information on cocoa production could be as a result of the confidence they had for themselves. The reason for this is not far-fetched; as most of the farmers relate with one another virtually on daily basis, there is a tendency to pass information on recommended technologies to one another frequently and easily. Also, farmers used radio as sources of information. Radio is a key information source for the most time-sensitive local news and information topics. This stressed the values and importance of radio as a source of information. Also, sourcing information through radio is attributed to the capability of extending messages to the audience irrespective of their location.

About $53 \%$ of the respondents sourced information through friends and relation. It could also be that the farmers were more disposed to non-professional sources of information (fellow farmers) than they were to professional sources. One of the reasons for this could be that friends and relations are closer to the farmers. The findings are in accordance with that of Nosheen et al. (2010). He noted that farmers, friends and relatives were the most significant sources of information used by the farmers to get information on sustainable agricultural practices. 


\section{Table 1: Distribution of respondents by their source of information}

\begin{tabular}{lc}
\hline $\begin{array}{l}\text { Information sources on cocoa } \\
\text { production }\end{array}$ & Yes (\%) \\
\hline Fellow cocoa farmers & 90.0 \\
Extension agents & 30.0 \\
Radio & 62.9 \\
Television & 30.0 \\
Farmers group & 45.7 \\
Friends and Relations & 52.9 \\
Newspapers & 12.9 \\
\hline
\end{tabular}

\section{Intra Household Roles in Cocoa Production}

Results in Table 2 reveals the intra-household roles in cocoa production. It shows that, men were involved in preparation of shade $(92.9 \%)$, planting of cocoa $(90.0 \%)$, weeding in the cocoa nursery site $(92.9 \%)$, land clearing for seedlings at permanent site $(100.0 \%)$. Though other household members were involved in land preparation, men played a prominent role. This is obvious because land preparation is a tedious operation, hence not many women will not be able to carry out the operation. The land preparation in cocoa involves clearing, pegging and digging of holes among others. These activities are energy consuming activities which is more suitable for men than women.

Other activities where men were more involved in cocoa production include transplanting of cocoa seedlings (84.3\%), weeding (97.1\%), fertilizer application $(60.0 \%)$, herbicides $(97.1 \%)$ and pesticides application $(100.0 \%)$. All these preplanting activities are necessary regular activities that must be done at the appropriate time. Other activities involved by men include removal of mistletoe (98.6\%), harvesting of cocoa pods (100.0\%) and bagging (94.5\%). Mistletoe are often found attached to cocoa tree; therefore, removal of mistletoe requires a carefulness in handling the activities to avoid cutting the stem of cocoa tree.

The production of cocoa is distinctly a man affair because men have more access to land, especially for the growing of cocoa in the South West Nigeria. The degree of access and control over land is a central factor affecting farmers' decisions. Men were more involved in cocoa production especially at pre-harvest stage as compared to women with relatively lower involvement in cocoa production activities. However, unlike in food crop production activities, where women had consistently higher contributions in all the activities than men, in cocoa production, women still had higher contributions than men in many post-harvest activities.

Women on the other hand were engaged in watering of cocoa seedlings at nursery $(80.0 \%)$ while male children were mostly involved in land clearing at the nursery $(84.3 \%)$, preparation of shade $(75.7 \%)$, planting of cocoa seed $(71.4 \%)$ among others. Female Children were involved in the removal of beans from cocoa pods $(85.7 \%)$ and sun-drying of cocoa beans (90.0\%). This implies that, all household members were involved in some important activities on the farm. The role played women and children 
Creative commons User License: CC BY-NC-ND

Abstracted by: EBSCOhost, Electronic Journals Service (EJS), Google Scholar, Journal Seek, Scientific Commons,

Food and Agricultural Organization (FAO), CABI and Scopus
Journal of Agricultural Extension

Vol. 22 (3) October, 2018

ISSN(e): 24086851; ISSN(Print); 1119944X

http://journal.aesonnigeria.org

http://www.ajol.info/index.php/iae

Email: editorinchief@aesonnigeria.org

are also very vital as that of the men. This underscores the heavy involvement of women in all agricultural activities.

The implication of these findings is that any policy action towards any of these activities could be directed towards household members handling such activities. For examples, all training related to preparation of shade at the cocoa nursery site should be directed towards male while those that related to watering of the seedlings at the nursery should be directed toward female. Individual members in the household has role to play in cocoa production.

Table 2: Intra household roles in cocoa production

\begin{tabular}{lcccc}
\hline Cocoa production activities & Men only & Women only & $\begin{array}{c}\text { Male } \\
\text { Children }\end{array}$ & $\begin{array}{c}\text { Female } \\
\text { Children }\end{array}$ \\
\hline land clearing at the nursery & & - & 84.3 & 21.4 \\
Preparation of shade & 92.9 & 24.3 & 75.7 & 24.3 \\
Planting cocoa seed & 90.0 & 12.9 & 71.4 & 14.3 \\
Watering at the nursery & 50.0 & 80.0 & 42.9 & 74.3 \\
Weeding nursery & 92.9 & 32.9 & 78.8 & 32.9 \\
Land clearing for seedling at permanent site & 100.0 & 8.6 & 81.4 & 8.6 \\
Transplanting of cocoa seedling to permanent site & 84.3 & 60.0 & 81.4 & 62.9 \\
Shading & 35.7 & 11.4 & 28.6 & 7.1 \\
Weeding & 97.1 & 22.9 & 81.4 & 14.3 \\
Mulching & 27.1 & 8.6 & 17.1 & 8.6 \\
Fertilizer application & 60.0 & 12.9 & 41.4 & 7.1 \\
Spraying of herbicides & 97.1 & - & 75.7 & - \\
Spraying of pesticides & 100.0 & - & 78.6 & - \\
Removal of mistletoe & 98.6 & 4.3 & 81.4 & - \\
Harvesting of cocoa pods & 100.0 & 27.1 & 84.3 & 15.7 \\
Transportation of pod & 28.6 & 34.3 & 25.7 & 30.0 \\
Removal of beans from the pod & 72.2 & 80.0 & 22.9 & 85.7 \\
Sun-drying & 42.9 & 82.9 & 38.6 & 90.0 \\
Bagging & 94.5 & 74.1 & 61.4 & 52.9 \\
\hline
\end{tabular}

${ }^{*}$ Multiple responses

\section{Constraints to Cocoa Production}

The major constraints to cocoa production were unavailability of labour to carry out essential farm activities ( $\overline{\mathrm{X}}=3.56)$, unfavourable prevailing weather condition ( $\overline{\mathrm{X}}=3.54)$ and poor extension agent-farmers contact ( $\bar{x}=3.51$ ) (Table 3$)$. In most cases, labour to carry out essential farm activities are not usually available all the time. Most of them were not willing to do farm work and the few that are available charge an exorbitant rate. This could be one of the reason why cocoa farmers used family labour on their farms. Unfavourable prevailing weather condition is another challenges facing farmers in cocoa farm. Insufficient rain, could affect the young growing cocoa seedlings both at the nursery and at permanent field, and at the same time when the sun is not available, it becomes very difficult to dry cocoa seedlings. Where the weather is favourable, the output will increase and vise-versa. Also, the poor extension agentfarmers contact could hinder cocoa production. Very few farmers were being visited by extension agents as a result of few extension agents available. In some cases, some were not visited at all. This is dangerous to agricultural production. As earlier indicated, the major sources of farmer's information on farming activities is through fellow farmers. Farmers will only apply the information available through their colleagues.

Other constraints to cocoa production include soil fertility issue ( $\bar{X}=3.43$ ), sale of adulterated chemicals to farmers $(\bar{X}=3.41)$, problem of land tenure system $(\bar{X}=3.34)$ 
Creative commons User License: CC BY-NC-ND

Abstracted by: EBSCOhost, Electronic Journals Service (EJS), Google Scholar, Journal Seek, Scientific Commons,

Food and Agricultural Organization (FAO), CABI and Scopus

\author{
Journal of Agricultural Extension \\ Vol. 22 (3) October, 2018 \\ ISSN(e): 24086851; ISSN(Print); 1119944X \\ http://journal.aesonnigeria.org \\ http://www.aiol.info/index.phpliae \\ Email: editorinchief@aesonnigeria.org
}

and Lack of government assistance $(\bar{x}=3.34)$. Coupled to this is the poor road network in most rural areas $(\overline{\mathrm{X}}=2.96)$. Continuous cropping on the same piece of land, without fertilization, can cause loss of soil fertility. Also when the soil is eroded by water or by wind, the nutrients are removed, worsening still the loss of soil fertility. Improving the soil fertility prevents soil erosion. Soil that is rich in organic matter has better structure and is less susceptible to being washed or blown away. When agrochemical is found to be adulterated, it could mean that the produce contains a pesticide chemical residue that is unsafe. This could have an effect on the plant. Restricted access to land also affects women's ability to obtain credit because banks often require land as collateral. A lower availability of credit implies less access to agricultural inputs such as fertilizer and pesticides

The major problem facing cocoa production in Nigeria is the acquisition of land for cocoa farming. More often, small scale farmers acquire land renting, pledging cocoa farm or giving it to another farmer in exchange for loan, which the farmer returns to the owner once the loan is paid, most and very significant too, is the main mode of land acquisition through family inheritance. Some of the farmers used lease system in their farm and this could affect cocoa production since it is a cash crop that lasted for years, the lease agreement could have reach the termination, hence they may not have the optimum profit from the plantation and it ends up been the land owners profit.

\section{Table 4: Constraints to cocoa production}

\begin{tabular}{lcc}
\hline Constraint & Mean $(\overline{\mathbf{X}})$ & $\begin{array}{c}\text { Std. } \\
\text { Deviation }\end{array}$ \\
\hline High cost of input like cocoa seedlings & 3.27 & 0.65 \\
Non availability of agrochemical and insecticides at the right time & 3.14 & 0.49 \\
Inadequate information on coca production in the study area & 2.61 & 0.74 \\
Unavailability of labour to carry out essential farm activities & 3.56 & 0.65 \\
Lack of funds to carry out farm operations in cocoa production & 3.23 & 0.48 \\
High cost of improved seedling & 3.29 & 0.91 \\
Soil fertility issue & 3.43 & 0.65 \\
Poor roads network & 2.96 & 0.39 \\
Unfavourable prevailing weather condition & 3.54 & 0.75 \\
Instability in government policies & 2.93 & 0.75 \\
Poor communication skill of extension staff & 3.26 & 0.94 \\
Lack of technical know-how on improved farming techniques & 3.23 & 0.57 \\
Poor extension agent farmer contact & 3.51 & 0.53 \\
Problem of land tenure system & 3.34 & 0.75 \\
Sale of adulterated chemicals to farmers & 3.41 & 0.69 \\
Poor feeder road networks & 2.90 & 1.02 \\
Lack of government assistance & 3.34 & 0.75 \\
Fluctuations in price & 2.96 & 0.58 \\
Lack of good storage facilities & 3.26 & 0.68 \\
Non availability of credit facility & 2.38 & 0.77 \\
Weed management facility & 3.19 & 3.03 \\
High incidence of pests and diseases & 2.90 & 0.46 \\
High risk and uncertainty in cocoa production & & 0.29 \\
\hline
\end{tabular}


Creative commons User License: CC BY-NC-ND

Abstracted by: EBSCOhost, Electronic Journals Service (EJS), Google Scholar, Journal Seek, Scientific Commons,

Food and Agricultural Organization (FAO), CABI and Scopus
Journal of Agricultural Extension

Vol. 22 (3) October, 2018

ISSN(e): 24086851; ISSN(Print); 1119944X

http://journal.aesonnigeria.org

http://www.ajol.info/index.php/iae

Email: editorinchief@aesonnigeria.org

\section{Conclusion and Recommendation}

Rural households were involved in cocoa production and with different role being played by both male and female. Energy consuming activities in the production of cocoa were executed more by male than female. Policy action should be directed towards household members handling such activities. The study recommends that issues relating to cocoa production should be addressed to specific individual household members performing such roles in order to improve the cocoa production.

\section{References}

Adeniyi, O. R. and Ogunsola, G.O. (2014). Cocoa Production and Related Social-Economic and Climate Factors: A Case Study of Ayedire Local Government Area of Osun State, Nigeria, Agricultural Science, 2(4): 1-13.

Akinnagbe O.M (2017). Impact of Cocoa Resuscitation Programme on Farmers' Livelihoods in South West, Nigeria. Agriculturae Conspectus Scientificus, 82(1): 39-47.

International Cocoa Organization $\{I C C O\}$ (2014). International Cocoa Organization Regional Seminar on the functioning of cocoa future markets and Econometric Modelling of the cocoa market, Indonesia, July 2014.

Michael, D. and Nzeka, U. (2011). Nigeria Cocoa Production Increases. USDA Foreign Agricultural Service, Global Agricultural Information Network.

Nigeria Agriculture Statistics (2014). The Nigeria agriculture profiles (subcategories). Retrieved from: http:/www.nationmaster.com/countryinfo/profiles/Nigeria/Agriculture.

Nosheen, F., T. Ali and M. Ahmad (2010). Analysis of gender specific sources of information regarding home and farm practices in Potohar region: a case study. The Journal of Animal and Plant Science 20(1): 56-59.

Olowolaju, P. S. (2014). An Assessment of Investment in Technology in Cocoa Processing Industry in Nigeria. Journal of Economics and Sustainable Development, 5(10):182188. 